\title{
ASSESSMENT OF PROVOCATIVE INFLAMMATORY ROLE OF TRISTETRAPROLIN AND TUMOR NECROSIS FACTOR ALPHA GENES EXPRESSION IN CHRONIC KIDNEY DISEASE
}

\section{AMANY A. SALEH ${ }^{1}$, SAFAA I. TAYEL ${ }^{1}$, NESREEN G. EL- HELBAWY ${ }^{1}$, KHALED MA. ELZORKANY ${ }^{2}$}

${ }^{1}$ Medical Biochemistry \& Molecular Biology and ${ }^{2}$ Internal Medicine Departments.Faculty of Medicine, Menoufia University. Egyp

Received 18 /9 /2019-Accepted 13 / 10 /2019

\begin{abstract}
Renal inflammation is a prominent feature of chronic kidney disease (CKD). The determinants of renal function decay are not completely comprehended. Tristetraprolin (TTP) and tumor necrosis factor (TNF$\alpha$ ) are immune mediators and affect renal inflammation. This study was planned to estimate gene expression of both TTP and TNF- $\alpha$ in CKD. One hundred fifty subjects were rolled in this study (55 CKD patients with hypertension, 45 CKD patients without hypertension and 50 healthy subjects). Renal functions, lipid profile $\&$ blood glucose were estimated from serum. TTP and TNF- $\alpha$ genes expression were assessed from whole blood samples by real time PCR. The results showed that TTP expression was significantly down-regulated while TNF- $\alpha$ was up-regulated in CKD patients with and without hypertension compared with healthy controls. It could be concluded that TTP and TNF- $\alpha$ may have a provocative inflammatory role in renal illness and may be utilized as promising biomarkers and therapeutic focus in CKD.
\end{abstract}

Keywords: Chronic kidney disease; Inflammation; Tristetraprolin, Tumor necrosis factor

* Correspondence Author (nesrin.eโhelbawy@yahoo.com) 


\section{INTRODUCTION}

Chronic kidney disease (CKD) is a developing worldwide general health burden with increasing mortality rates throughout the last twenty years (Abd Elhafeez et al., 2018). CKD is manifested by age-related renal function impairment and decline in glomerular filtration rate (GFR) expanded especially in hypertension and diabetes (Hill et al., 2016).

Inflammation has a critical role in CKD development and progression. Additionally, low-grade and persistent inflammation became a constant component of CKD being associated with disease progression (Mihai et al., 2018) .

Tristetraprolin (TTP) called also ZFP36 is a zinc finger protein which has a fundamental role as an anti-inflammatory protein and is associated with numerous diverse physiological and pathological responses (Liu et al., 2015). It interacts with an AU-rich mRNA that is associated with mRNA degradation post transcriptionally to restrict the expression of various pro-inflammatory cytokines. TTP is managed by phosphorylation which is MAPK-dependent (Rahman et al., 2016).

Cytokines are proteins molecules delivered by an entire scope of various cell types resulting in alteration of both the immunological and inflammatory responses. They are enrolled in the pathogenesis of CKD. Endothelial injuries which are usually accompanied by the release of particular modifiers that might set up the inflammatory response (Ortega \& Alessia, 2010) .

Tumor necrosis factor (TNF- $\alpha$ ) is a trimer $34 \mathrm{kDa}$ cytokine associated with the progression and pathogenesis of inflammatory reactions (AlLamki \& Mayadas, 2015) with evidences from previous studies which suggest that TTP regulates and controls TNF- $\alpha$ expression post transcriptionally (Zhao et al., 2016).

Few studies reported TTP expression in renal diseases, so we aimed to investigate both the anti-inflammatory role of TTP and pro- 
inflammatory extent of TNF- $\alpha$ expressions in CKD with and without hypertension.

\section{MATERIALS AND METHODS}

\section{Subjects}

This study was achieved in Medical Biochemistry and Molecular Biology Department, Faculty of Medicine, Menoufia University in association with Nephrology Unit of Internal Medicine Department, Menoufia University Hospitals. All subjects were recruited during the period from January 2018 to April 2019. It included 150 participants who were arranged into 3 main groups: Group I: included 55 CKD patients with hypertension(not diabetic nor autoimmune and idiopathic) with mean age $(53.80 \pm 10.8)$. They were 30 males and 25 females. Group II: included 45 CKD patients without hypertension (30 diabetic nephropathy (DN) and 15 autoimmune and idiopathic nephropathy) with mean age $(51.80 \pm 13.6)$ they were 22 males and 23 females. Group III: Included 50 ages and sex matched healthy volunteers as controls with mean age $(48.50 \pm 12.81)$ they were 35 males and 15 females.

CKD is characterized as aberration of either structure or function of the kidney, present for over three months with a decreased eGFR $<60$ $\mathrm{ml} / \mathrm{min} / 1.73 \mathrm{~m}^{2}$, and urine albumin excretion rate (AER) $\geq 30 \mathrm{mg} / 24$ hours, approximately equivalent to urine albumin/ creatinine ratio (ACR) $\geq 30 \mathrm{mg} / \mathrm{g}$ (Levey and Coresh, 2012). The latest European guidelines retain the previous criteria of hypertension (ie, BP >140/90 $\mathrm{mm} \mathrm{Hg}$ ) but the American guidelines lowered the threshold to define hypertension to $>130 / 80 \mathrm{~mm} \mathrm{Hg}$. Yet, both guidelines recommend the same therapeutic BP aim of $<130 / 80 \mathrm{~mm} \mathrm{Hg}$ ( Chopra H.K.and Ram C.V. 2019).

Patients with any cardiovascular disease other than hypertention, inflammatory diseases, acute kidney diseases and end-stage renal disease (ESRD) were excluded from our study. This investigation was completed as per the ethics of the world medical association (Declaration of Helsinki). All participants in this investigation gave an informed consent approved by Local Ethical Research Committee in Menoufia university Faculty of Medicine 


\section{METHODS}

This was done in the laboratory of Medical Biochemistry and Molecular Biology Department. Ten (10) $\mathrm{ml}$ of venous blood were collected from all subjects after overnight fasting, and were divided as follow: $5 \mathrm{ml}$ of blood were taken into EDTA containing tubes, for measuring glycated hemoglobin (HbA1c) by colorimetric method utilizing [Teco diagnostics kit, USA] and for RNA extraction and $4 \mathrm{ml}$ were taken in plain vacutainer tube, left 15 minutes, centrifuged at $3000 \mathrm{rpm}$ for 10 minutes for the separation of serum for further determination of renal function tests \& lipid profile. Mod Berthelot enzymatic colorimetric method was followed using (DIAMOND diagnostics kit, Germany) for measuring serum urea, while fixed rate kinetic chemical method was applied for estimation of serum creatinine using kits supplied by (DIAMOND diagnostics kit, Germany).

Determination of GFR by MDRD formula $=$ Estimated GFR $\left(\mathrm{ml} / \mathrm{min} / 1.73 \mathrm{~m}^{2}\right)=186.3 \times$ (serum creatinine $)^{-1.154} \mathrm{x} \mathrm{Age}^{-0.203} \times(0.742$ if female) x (1.21 if African American) (Levey et al., 2006). Measurement of lipid profile : high density lipoproteins cholesterol (HDLc), total cholesterol (TC) and triacylglycerol (TG) using standard enzymatic colorimetric kits (Spinreact diagnostics kit, Spain). Low density lipoprotein cholesterol (LDL-c) was resolved from the equation (LDLc) $=\mathrm{TC}-(\mathrm{TG} / 5+\mathrm{HDLc})$ as $\mathrm{TG}$ measurements not surpass $400 \mathrm{mg} / \mathrm{dl}$ (Wallach, 1996). The last one $\mathrm{ml}$ of blood was taken into tube containing sodium fluoride for estimation of fasting blood glucose (FBG) and postprandial blood glucose (PBG) by glucose oxidase method using (Spinreact diagnostics kit, Spain).

Fifteen (15) $\mathrm{ml}$ of fresh morning urine samples were collected in sterile container from every subject for measurement of creatinine and micro albumin and calculation of ACR. Urinary albumin was estimated by a solid phase enzyme linked immunosorbent assay (ELISA) method utilizing kit from [DRG International Inc., USA], and adjusted for urinary creatinine for precise estimation of urinary ACR / 24 hours.

\section{Real-time PCR for quantitative assay of TTP and TNF- $\alpha$ genes}

This part of the work was done in the central laboratory of faculty of medicine,Menoufia university. RNA was extracted from whole blood 
using (The Invitrogen Pure Link RNA Mini Kit) and then RNA quality and purity were assured. Storage in $-80^{\circ} \mathrm{C}$ was applied for extracted RNA till use. For cDNA synthesis, reverse transcription step (RT-PCR) was done using (My Taq T monestep RT PCR kit), and steps were programmed utilizing thermal cycler Applied Biosystems 2720 (Bioline, Singapore, USA). SYBR green method was utilized for cDNA amplification for quantification of TTP and TNF- $\alpha$ genes expression by (SensiFAST TM SYBR Lo-ROX Kit, Bioline). Primers used in reactions were: TTP primer sequence: Forward 5'-

GGAGTGTCTTCCGAGGTTCTT-3'

Reverse 5-'GCTACTTGCTTTTGGAGGGTAAT -3' ( Liu et al., 2015).TNF- $\alpha$ primer sequence:

Forward 5'- CTGAACTTCGGGGTGATCG -3'

Reverse 5'- GCTTGGTGGTTTGCTACGAC -3' (Nourian et al., 2017). Glyceraldehyde 3- phosphate dehydrogenase (GAPDH( reference gene) primer sequence:

Forward 5'-TGATGACATCAAGAAGGTGGTGAAG-3', Reverse 5'-TCCTTGGAGGCCATGTGGGCCAT-3'(Faniello et al., 2008).

Applied Biosystems 7500 software version 2.0.1 was used to determine the relative quantification (RQ) of gene expression using comparative $\Delta \Delta \mathrm{Ct}$ method (Livak KJ and Schmittgen TD ,2001) where the target amount of TTP (Figure 1 A \& B) and TNF- $\alpha$ (Figure 2 A \& B) genes, were normalized to an endogenous reference gene (GAPDH) and relative to a control which is the mean CT of all the healthy control. Melting curve analysis was done for each run to confirm amplification specificity and lack of primer dimers.

\section{Statistical Analysis}

IBM SPSS software package version 20.0. (Armonk, NY: IBM Corp) was used for data analysis. For comparing between more than two groups, F-test (ANOVA) for normally distributed quantitative variables and Post Hoc test (LSD) was applied for pair wise comparisons.Chi square test was applied for the relation between categorized variable as gender. Correlation between two distributed abnormally quantitative 
variable was calculated by spearman coefficient. Significance of the obtained results was assessed at the $5 \%$ level.

\section{RESULTS}

Results following data analysis showed that age and gender were matched among groups. Using Anova test among 3 studied groups demonstrated that BMI, FBG, PBG, ACR, HbA1c, urea, creatnine, eGFR, SBP, DBP, lipid profile were significantly different among groups $(\mathrm{P}<0.001)$. Furthermore, TTP $(\mathrm{P}<0.004)$ and TNF- $\alpha(\mathrm{P}<0.001)$ relative expressions significantly differ among groups. Comparison between CKD patients with hypertension (group I) and CKD patients without hypertension (group II) showed that group I had lower BMI $(\mathrm{P}=0.04)$, FBG, PBG, HbA1c, eGFR ( $<<0.001)$, while significantly higher ACR, urea, creatnine, SBP, DBP, TG, TC and TNF- $\alpha$ expression $(\mathrm{P}<0.001)$ while TTP expression, HDLc and LDLc did not show any significant difference $(\mathrm{P}>0.05)$. On comparing group I and healthy controls (group III), group I had elevated BMI, ACR, urea, creatnine, SBP, DBP, TG, TC, LDLc, TNF- $\alpha$ expression $(\mathrm{P}<0.001)$ while less eGFR, HDLc, TTP expression $(\mathrm{P}<0.001)$ compared with group III ,While FBG, PBG, HbA1c did not differ between groups $(\mathrm{P}>0.05)$. in addition, results comparing group II and healthy controls (group III), clarified that group II had significantly increased values of BMI, ACR, urea, creatnine, FBG, PBG, HbA1c TG, TC, LDLc $(\mathrm{P}<0.001)$, TNF- $\alpha$ expression $(\mathrm{P}<0.01)$ while lower TTP expression $(\mathrm{P}<0.01)$, HDLc , eGFR $(\mathrm{P}<0.001)$ versus group III and blood sugar indices were not significant between groups (P>0.05) (Table 1).

As regard the correlation table between TTP expression and other measured parameters, demonstrated significant negative correlations with SBP $(r=-0.28, P=0.03)$, DBP $(r=-0.30, P=0.02)$, eGFR $(r=-0.29$, $\mathrm{P}=0.03)$, TNF- $\alpha$ expression $(\mathrm{r}=-0.27, \mathrm{P}=0.04)$ in group $\mathrm{I}$. In addition TTP showed significant negative correlations with FBG $(\mathrm{r}=-0.32, \mathrm{P}=0.03)$, PBG $(\mathrm{r}=-0.30, \mathrm{P}=0.05)$, eGFR $(\mathrm{r}=-0.32, \mathrm{P}=0.02)$, TNF- $\alpha$ expression $(\mathrm{r}=$ $-0.29, \mathrm{P}=0.04)$ in group II while no significant correlation was detected in group III (Table 2). Considering TNF- $\alpha$ correlations, we detected significant positive correlations with SBP $(r=0.33, \mathrm{P}=0.01)$, DBP $(r=$ 
$0.28, \mathrm{P}=0.03)$, while significant negative correlation with eGFR $(\mathrm{r}=$ $0.27, \mathrm{P}=0.04)$, in group I. Furthermore, TNF- $\alpha$ showed significant positive correlations with $\mathrm{FBG}(\mathrm{r}=0.28, \mathrm{P}=0.04), \mathrm{TG}(\mathrm{r}=0.29, \mathrm{P}=0.05)$, while significant negative correlation was detected with eGFR $(\mathrm{r}=-0.29$, $\mathrm{P}=0.04$ ) in group II while no correlation was found in group III (Table 2).

Receiver operating characteristics (ROC) curve was constructed to discriminate $\mathrm{CKD}$ patients with hypertension from normal healthy individuals. The best TTP cutoff value was $\leq 0.77$, (AUC $=0.884$, $\mathrm{P}=<0.001$ ), with sensitivity $92.7 \%$ and specificity $76.0 \%$ (Figure 1C). while for TNF- $\alpha$ the best cutoff value was $\geq 1.15$, (AUC $=0.960$, $\mathrm{P}=<0.001$ ), with sensitivity $94.5 \%$ and specificity $84.7 \%$ (Figure 2C) (Table 3).

Moreover, TTP at cutoff value $\leq 0.74$, $(\mathrm{AUC}=0.825, \mathrm{P}=<0.001)$, with sensitivity $84.4 \%$ and specificity $76.0 \%$ (Figure 1D) and TNF- $\alpha$ at cutoff value $\geq 1.35$, (AUC $=0.945, \mathrm{P}=<0.001$ ), with sensitivity $93.3 \%$ and specificity $90.0 \%$ (Figure 2D) could be used to discriminate CKD patients without hypertension from healthy individuals (Table 4).

Regarding the positivity rates for both TTP and TNF- $\alpha$ genes expression,the study showed significant difference between both studied groups and control group(Table 5).

The correlations between positivity rates for both TTP and TNF- $\alpha$ genes expression and the other studied parameters declaired significant positive correlation between positivity rates of TTP gene expression and urea but significant negative correlations with eGFR, SBP and DBP in group I .While in group II it showed significant positive correlations with FBG and PBG but significant negative correlations with eGFR and TNF- $\alpha$ gene expression. Considering positivity rates of TNF- $\alpha$ gene expression there were significant positive correlations with SBP and DBP and negative correlations with eGFR,HDL $\mathrm{c}$ and TTP gene expression in group I. While showed significant positive correlation with FBG and negative one with eGFR in group II (Table 6). 
Table (1) Comparison of demographic and laboratory parameters among studied groups

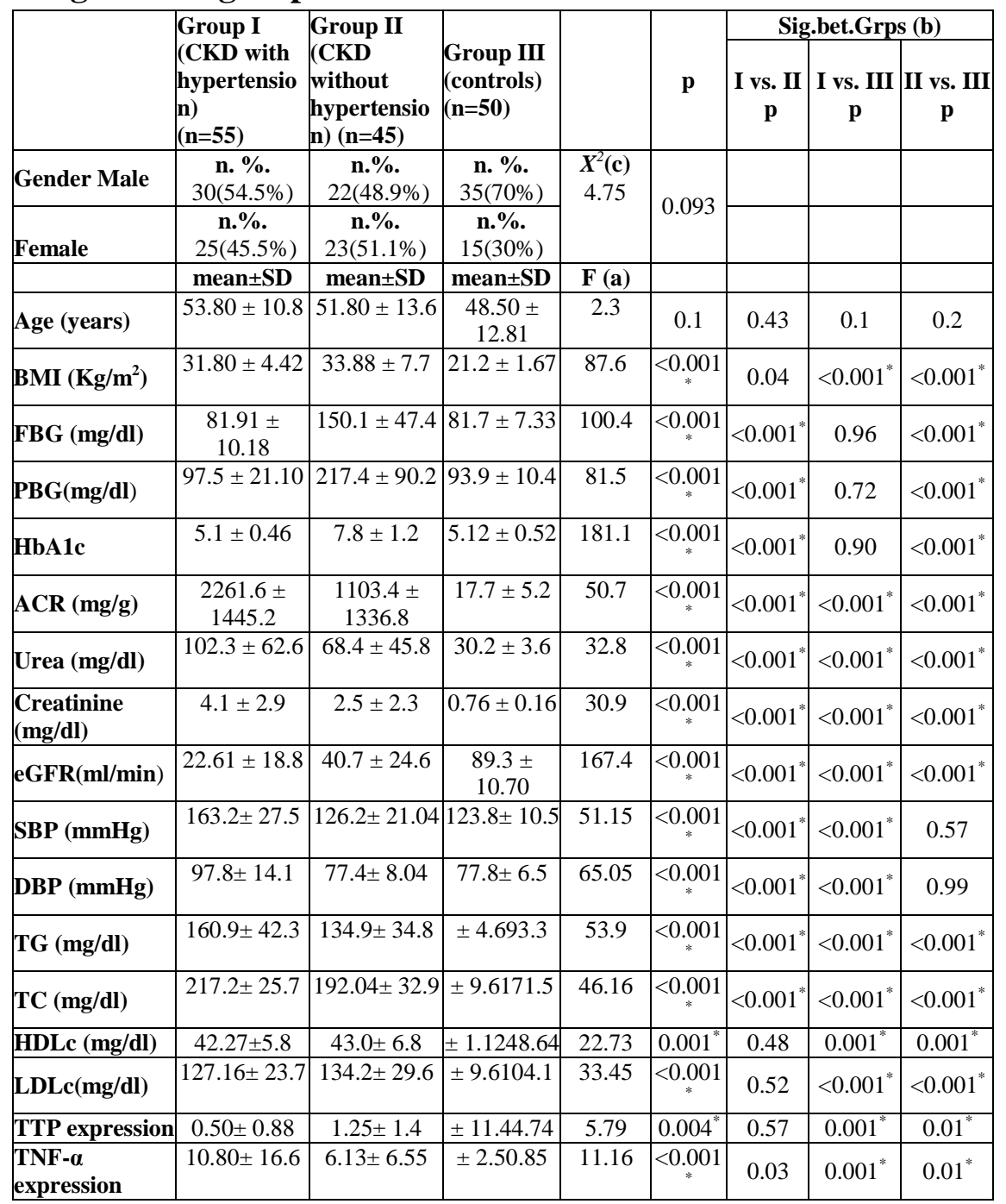
*: Statistically significant at $\mathrm{p} \leq 0.05$
(a) ANOVA test
(b) Post hoc test

(c) $X^{2}$ Chi square test 


\section{Table (2): Correlation between TTP and TNF- $\alpha$ genes expression} and different studied parameters.

\begin{tabular}{|c|c|c|c|c|c|c|}
\hline & \multicolumn{3}{|c|}{ TTP gene expression } & \multicolumn{3}{|c|}{ TNF- $\alpha$ gene expression } \\
\hline & $\begin{array}{l}\text { Group I } \\
\text { (CKD } \\
\text { patients with } \\
\text { hypertension) } \\
(\mathbf{n}=55)\end{array}$ & $\begin{array}{l}\text { Group II } \\
\text { (CKD patients } \\
\text { without } \\
\text { hypertension) } \\
(\mathrm{n}=45)\end{array}$ & $\begin{array}{l}\text { Group III } \\
\text { (controls) } \\
(\mathbf{n}=50)\end{array}$ & $\begin{array}{l}\text { Group I } \\
\text { (CKD } \\
\text { patients with } \\
\text { hypertension) } \\
(\mathbf{n}=55)\end{array}$ & $\begin{array}{l}\text { Group II } \\
\text { (CKD } \\
\text { patients } \\
\text { without } \\
\text { hypertension) } \\
(n=45)\end{array}$ & $\begin{array}{l}\text { Group III } \\
\text { (controls) } \\
(\mathbf{n}=50)\end{array}$ \\
\hline & $\mathbf{r}_{\mathrm{s}}$ & $\mathbf{r}_{\mathrm{s}}$ & $\mathbf{r}_{\mathrm{s}}$ & $\mathbf{r}_{\mathrm{s}}$ & $\mathbf{r}_{\mathrm{s}}$ & $\mathbf{r}_{\mathrm{s}}$ \\
\hline Age (years) & 0.001 & -0.03 & -0.07 & $0.03-$ & -0.216 & 0.05 \\
\hline BMI $\left(\mathrm{Kg} / \mathrm{m}^{2}\right)$ & -0.119 & $0.05-$ & -0.17 & 0.03 & -0.05 & 0.12 \\
\hline FBG (mg/dl) & 0.035 & $0.32^{*}$ & -0.24 & 0.02 & $0.28^{*}$ & 0.09 \\
\hline PBG(mg/dl) & -0.07 & $0.30^{*}$ & 0.05 & 0.18 & 0.05 & 0.15 \\
\hline HbA1c & 0.016 & 0.15 & -0.08 & 0.02 & 0.18 & 0.05 \\
\hline $\operatorname{ACR}(\mathrm{mg} / \mathrm{g})$ & 0.14 & -0.03 & -0.20 & $0.01-$ & 0.08 & 0.11 \\
\hline Urea (mg/dl) & 0.14 & -0.20 & -0.19 & $0.13-$ & 0.03 & $0.04-$ \\
\hline $\begin{array}{l}\text { Creatinine } \\
\text { (mg/dl) }\end{array}$ & 0.16 & -0.06 & -0.08 & -0.10 & -0.02 & -0.02 \\
\hline $\begin{array}{l}\text { eGFR } \\
(\mathrm{ml} / \mathrm{min})\end{array}$ & $-0.29^{*}$ & $-0.32^{*}$ & -0.13 & $-0.27^{*}$ & $-0.29^{*}$ & -0.09 \\
\hline $\begin{array}{l}\text { SBP } \\
(\mathrm{mmHg})\end{array}$ & $-0.28^{*}$ & 0.119 & 0.09 & $0.33^{*}$ & 0.009 & 0.14 \\
\hline $\begin{array}{l}\text { DBP } \\
(\mathrm{mmHg})\end{array}$ & $-0.30^{*}$ & 0.08 & -0.17 & $0.28^{*}$ & 0.114 & 0.16 \\
\hline TG (mg/dl) & -0.002 & 0.13 & 0.10 & -0.002 & $0.29^{*}$ & 0.03 \\
\hline TC (mg/dl) & -0.12 & 0.03 & 0.001 & -0.12 & 0.001 & -0.01 \\
\hline $\begin{array}{l}\text { HDLc } \\
\text { (mg/dl) }\end{array}$ & -0.05 & -0.18 & 0.19 & -0.05 & -0.17 & 0.10 \\
\hline $\begin{array}{l}\text { LDLc } \\
(\mathrm{mg} / \mathrm{dl})\end{array}$ & 0.007 & 0.05 & $0.04-$ & 0.007 & -0.05 & -0.02 \\
\hline $\begin{array}{l}\text { TNF- } \alpha \\
\text { expression }\end{array}$ & $-0.27^{*}$ & $-0.29^{*}$ & -0.09 & & & \\
\hline $\begin{array}{l}\text { TTP } \\
\text { expression }\end{array}$ & & & & $-0.27^{*}$ & $-0.29^{*}$ & -0.09 \\
\hline
\end{tabular}

$\mathrm{r}_{\mathrm{s}}$ : Spearman coefficient, *: Statistically significant at $\mathrm{p} \leq 0.05$ 
Table (3): Performance characteristics of TTP and TNF- $\alpha$ genes expression to discriminate CKD patients with hypertension from normal healthy individuals

\begin{tabular}{|c|c|c|c|c|c|}
\hline & है & 己 & $\begin{array}{l}7 \\
0 \\
2\end{array}$ & 矛 & 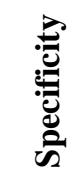 \\
\hline TTP gene expression & $\leq 0.77$ & $0.884^{*}$ & $0.815-0.954$ & 92.7 & 76.0 \\
\hline $\begin{array}{l}\text { TNF- } \alpha \text { gene } \\
\text { expression }\end{array}$ & $\geq 1.15$ & $0.960^{*}$ & $0.924-0.997$ & 94.5 & 84.7 \\
\hline
\end{tabular}

$*:$ Statistically significant at $\mathrm{p} \leq 0.05$

Table (4): Performance characteristics of TTP and TNF- $\alpha$ genes expression to discriminate CKD patients without hypertension from normal healthy individuals

\begin{tabular}{|c|c|c|c|c|c|}
\hline & 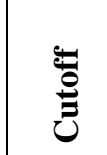 & $\underset{\mho}{\circlearrowright}$ & $\begin{array}{l}\text { ت } \\
2 \\
2\end{array}$ &  & 窇 \\
\hline TTP gene expression & $\leq 0.74$ & $0.825^{*}$ & $0.738-0.912$ & 84.4 & 76.0 \\
\hline TNF- $\alpha$ gene expression & $\geq 1.35$ & $0.945^{*}$ & $0.890-1.00$ & 93.3 & 90.0 \\
\hline
\end{tabular}

*: Statistically significant at $\mathrm{p} \leq 0.05$ 
Table(5): Comparison of positivity rates of TTP and TNF- $\alpha$ genes expression among studied groups.

\begin{tabular}{|c|c|c|c|c|c|c|c|c|}
\hline & \multirow{2}{*}{$\begin{array}{l}\text { Group I } \\
\text { CKD with } \\
\text { hypertensi } \\
\text { on }\end{array}$} & \multirow{2}{*}{$\begin{array}{l}\text { Group II } \\
\text { CKD } \\
\text { without } \\
\text { hypertension }\end{array}$} & \multirow{2}{*}{$\begin{array}{l}\text { Group III } \\
\text { controls }\end{array}$} & \multirow{2}{*}{ F (a) } & \multirow[t]{2}{*}{$\mathbf{P}$} & \multicolumn{3}{|c|}{ Sig.bet.Grps(b) } \\
\hline & & & & & & $\begin{array}{c}\text { I vs. } \\
\text { II } \\
\text { P }\end{array}$ & $\begin{array}{c}\text { I } \\
\text { vs. } \\
\text { III } \\
\text { P }\end{array}$ & $\begin{array}{l}\text { II vs. } \\
\text { III } \\
\quad \text { P }\end{array}$ \\
\hline $\begin{array}{l}\text { Positivity } \\
\text { rates of } \\
\text { TTP } \\
\text { expression } \\
\text { mean } \pm \text { SD }\end{array}$ & $\begin{array}{c}(n=47) \\
0.22 \pm 0.12\end{array}$ & $\begin{array}{c}(n=25) \\
0.31 \pm 0.20\end{array}$ & $\begin{array}{c}(n=50) \\
4.74 \pm 11.4\end{array}$ & 5.47 & $0.005^{*}$ & 0.95 & $\begin{array}{l}\mathbf{0 . 0} \\
\mathbf{0 3}^{*}\end{array}$ & $0.016^{*}$ \\
\hline $\begin{array}{l}\text { Positivity } \\
\text { rates of } \\
\text { TNF- } \alpha \\
\text { expression } \\
\text { mean } \pm \text { SD }\end{array}$ & $\begin{array}{c}(\mathrm{n}=43) \\
13.7 \pm 7.6\end{array}$ & $\begin{array}{c}(n=38) \\
7.15 \pm 6.1\end{array}$ & $\begin{array}{c}(n=50) \\
0.85 \pm 2.5\end{array}$ & 16.08 & $0.001^{*}$ & 0.008 & $\begin{array}{l}\mathbf{0 . 0} \\
\mathbf{0 1}^{*}\end{array}$ & $0.008^{*}$ \\
\hline
\end{tabular}

*: Statistically significant at $p \leq 0.05$ (a) ANOVA test (b) Post hoc test 
Table (6): Correlation between positivity rates of TTP and TNF- $\alpha$ genes expression and different studied parameters.

\begin{tabular}{|c|c|c|c|c|}
\hline & \multicolumn{2}{|c|}{$\begin{array}{l}\text { positivity rates of TTP gene } \\
\text { expression }\end{array}$} & \multicolumn{2}{|c|}{$\begin{array}{l}\text { positivity rates of TNF- } \alpha \text { gene } \\
\text { expression }\end{array}$} \\
\hline & $\begin{array}{l}\text { (Group I) } \\
\text { CKD with } \\
\text { hypertension } \\
(\mathrm{n}=47)\end{array}$ & $\begin{array}{l}\text { (Group II) } \\
\text { CKD without } \\
\text { hypertension } \\
(\mathrm{n}=25)\end{array}$ & $\begin{array}{l}\text { (Group I) } \\
\text { CKD with } \\
\text { hypertension } \\
(\mathrm{n}=43)\end{array}$ & $\begin{array}{l}\text { (Group II) } \\
\text { CKD without } \\
\text { hypertension } \\
(\mathrm{n}=38)\end{array}$ \\
\hline & $\mathbf{r}_{\mathrm{s}}$ & $\mathbf{r}_{\mathrm{s}}$ & $\mathbf{r}_{\mathrm{s}}$ & $\mathbf{r}_{\mathrm{s}}$ \\
\hline Age (years) & 0.20 & 0.37 & -0.03 & -0.19 \\
\hline BMI $\left(\mathrm{Kg} / \mathrm{m}^{2}\right)$ & 0.10 & -0.02 & 0.06 & -0.04 \\
\hline FBG (mg/dl) & -0.05 & $0.33^{*}$ & -0.08 & $0.29^{*}$ \\
\hline PBG(mg/dl) & -0.12 & $0.31^{*}$ & 0.24 & 0.05 \\
\hline HbA1c & -0.17 & 0.15 & -0.01 & -0.03 \\
\hline $\operatorname{ACR}(\mathrm{mg} / \mathrm{g})$ & 0.21 & -0.03 & -0.12 & 0.15 \\
\hline Urea (mg/dl) & $0.28^{*}$ & -0.20 & $0.16-$ & 0.05 \\
\hline $\begin{array}{l}\text { Creatinine } \\
\text { (mg/dl) }\end{array}$ & 0.26 & -0.06 & -0.10 & -0.02 \\
\hline $\begin{array}{l}\text { eGFR } \\
(\mathrm{ml} / \mathrm{min})\end{array}$ & $-0.34^{*}$ & $-0.32^{*}$ & $-0.27^{*}$ & $-0.30^{*}$ \\
\hline SBP (mmHg) & $-0.29^{*}$ & 0.119 & $0.34^{*}$ & 0.10 \\
\hline DBP (mmHg) & $-0.31^{*}$ & 0.08 & $0.29^{*}$ & 0.06 \\
\hline TG (mg/dl) & -0.17 & 0.13 & 0.08 & 0.28 \\
\hline TC (mg/dl) & 0.05 & 0.03 & -0.01 & 0.16 \\
\hline HDLc (mg/dl) & 0.02 & -0.18 & $-0.39^{*}$ & -0.18 \\
\hline LDLc (mg/dl) & 0.007 & 0.05 & -0.02 & 0.07 \\
\hline $\begin{array}{l}\text { TNF- } \alpha \\
\text { expression }\end{array}$ & -0.03 & $-0.29^{*}$ & & \\
\hline $\begin{array}{l}\text { TTP } \\
\text { expression }\end{array}$ & & & $-0.28^{*}$ & -0.04 \\
\hline
\end{tabular}

$r_{s}$ : Spearman coefficient, *: Statistically significant at $p \leq 0.05$ 

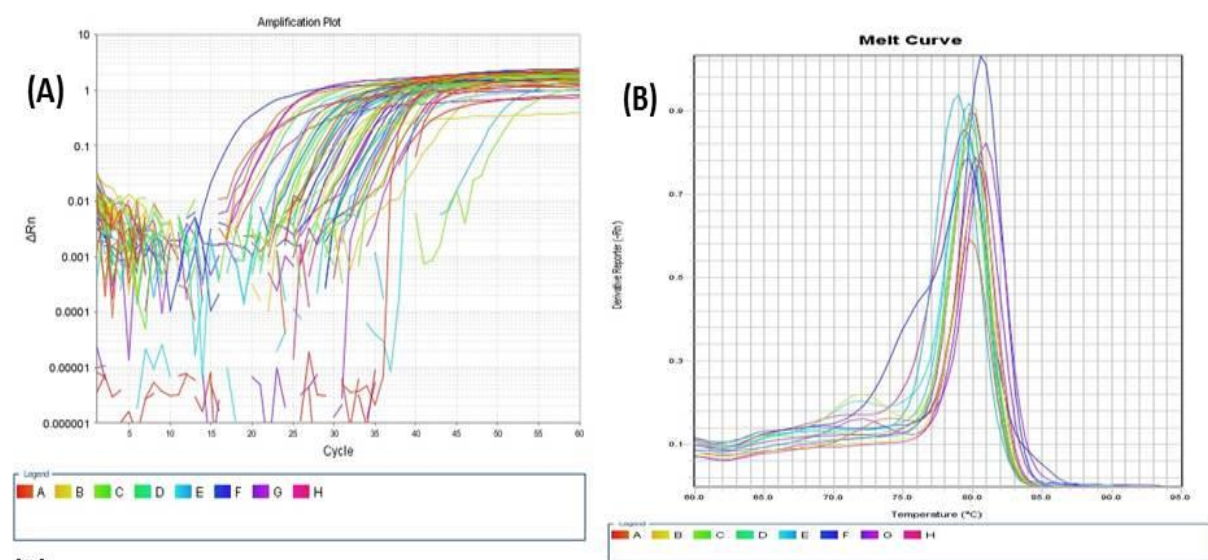

(C)

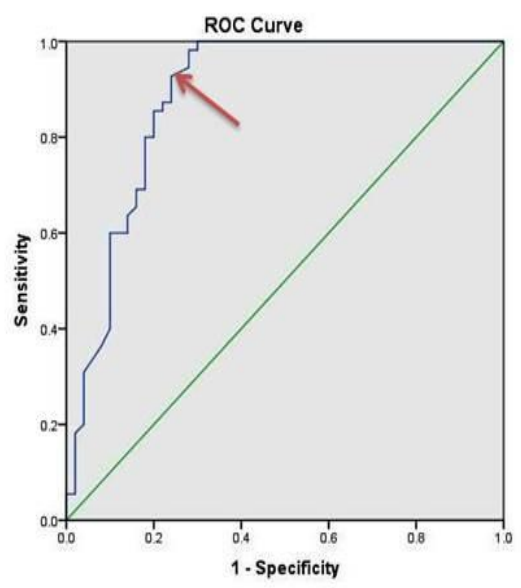

(D)

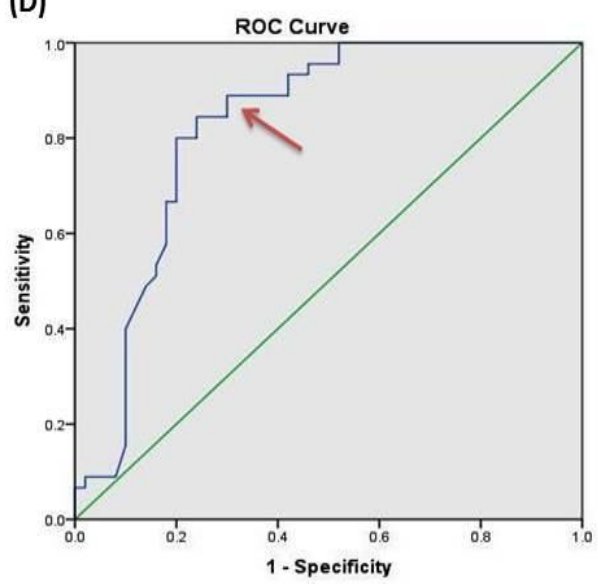

Figure 1: A- Amplification plot of TTP gene expression (normalized fluorescence signal $(\triangle \mathrm{Rn})$ plotted versus cycle number). B- Melting curve analysis of TTP gene expression. C- ROC curve for TTP gene expression in CKD with hypertension versus normal healthy individuals. D- ROC curve for TTP gene expression in CKD without hypertension versus normal healthy individuals. 

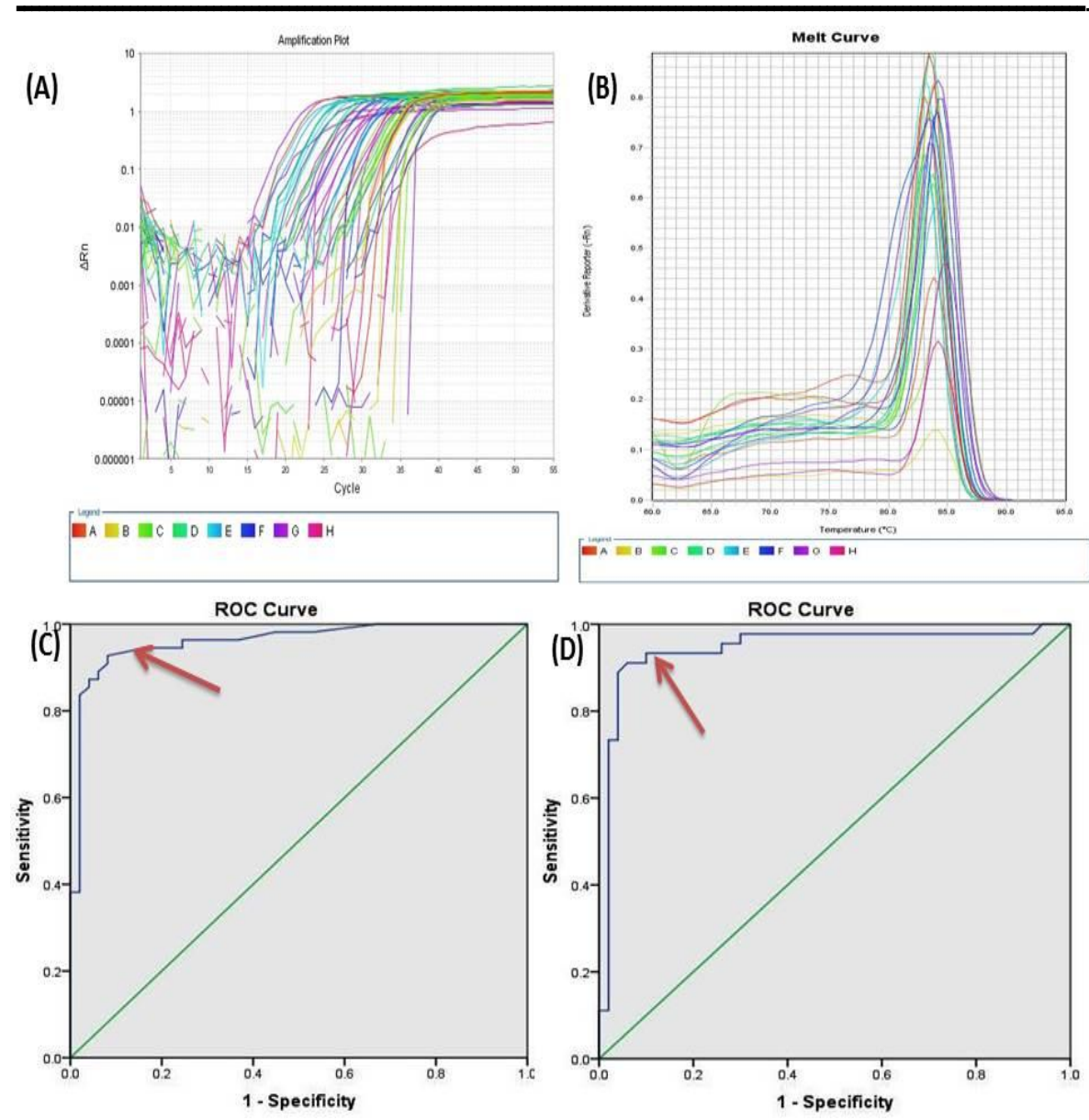

Figure 2: A- Amplification plot of TNF- $\alpha$ gene expression. B- Melting curve analysis of TNF- $\alpha$ gene expression. C- ROC curve for TNF- $\alpha$ gene expression in CKD with hypertension versus normal healthy individuals. D- ROC curve for TNF$\alpha$ gene expression in CKD without hypertension versus normal healthy individuals.

\section{DISCUSSION}

Diabetes mellitus and hypertension are significant reasons of CKD. Both induce development of CKD to end stage renal disease( ESRD) which worsens illness morbidity and mortality. Post-transcriptional regulation of mRNA stability assumes a pivotal role in CKD. It underlies the limit of renal cells to form transient protein assemblies 
like stress granules SGs and P-bodies, that interact with translational and degradation processes to adjust genes expression predisposing to disease phenotypes (Feigerlová \& Battaglia-Hsu, 2017).

TNF- $\alpha$ has a pivotal function in the occurrence of inflammatory diseases. TNF- $\alpha$ overexpression initiates TTP protein, an RNAbinding molecule that control mRNA degeneration and stability of, which subsequently down -regulates TNF and its gene expression, bringing in anti-inflammatory properties (Chen et al., 2012).

This study demonstrated significant down- regulation of TTP expression while significant up- regulation of TNF- $\alpha$ in CKD patients with and without hypertension compared with healthy ones that indicate fulminant role of inflammatory mediators in pattern of CKD development. Moreover, we explored significant correlations between TTP and BP and eGFR in group I and with blood sugar and eGFR in group II. Also, TNF- $\alpha$ showed similar correlation that may in part explain differential expressions of both TTP and TNF- $\alpha$ in CKD. In addition, TTP showed negative correlation with TNF- $\alpha$ in CKD that proves inverse regulation between both markers.

In accordance with these findings, Xiao et al. (2014) recognized that TTP expression was declined in uraemia, and further decrease was explored in the peritoneal dialysis and suggested that TTP was downregulated by glucose excess and chronic inflammation. Additionally, Liu et al., (2015) demonstrated that TTP expression was decreased in patients with clinical proteinuria, with lower paralleled decrease in type 2 diabetic patients (T2D) with a diminished extent of diabetic nephropathy (DN)

TTP is among the proteins that interact with adenine - uridine rich elements (AREs) leading to mRNA turnover by means of sequence located on the 3'untranslated regions of mRNAs encoding certain inflammatory mediators, involving those of cyclooxygenase 2 (COX2), TNF $\alpha$, IL-10 and MCP-1. TTP was categorized as an inhibiting agent to excessive TNF- $\alpha$ synthesis through its mRNA destabilization (Astakhova et al., 2018). 
Systemic inflammation caused by TTP lack prompts endothelial dysfunction which is a typical feature of hypertension and extreme disease phenotype that can be improved partially by an anti-TNF- $\alpha$ treatment (Bollmann et al., 2014).

Zhang et al. (2019) noticed high levels of TNF- $\alpha$, in DN with microalbuminuria and macroalbuminuria than healthy ones and T2D with normoalbuminuria and added that TNF- $\alpha$ was set as a potential biomarker for the recognition of early-stage $\mathrm{DN}$.

Puszkarska et al. (2019) reported that patients with hypertension and early renal injury are described by increased TNF levels in blood and in 24-hour urine than healthy ones.

TNF- $\alpha$ is largely involved in renal inflammation and glomerular damage stimulated by immune complex deposition. TNF- $\alpha$ expression in renal tissues is up-regulated in glomerulonephritis. TNF- $\alpha$ likewise displays both proinflammatory and immunosuppressive porperties. On the other hand, few reports have recommended advantages of antiTNF- $\alpha$ therapy in renal inflammation, despite the fact that this should be convincingly appeared in randomized controlled trials (Ernandez and Mayadas, 2009).

Using ROC curve analysis TTP and TNF- $\alpha$ were of diagnostic value at cutoff $>0.77$ and $>1.15$, with sensitivity $92.7 \%$ and $94.5 \%$ respectively for CKD with hypertension. Additionally, TTP and TNF$\alpha$ at cutoff $>0.74,>1.35$, with sensitivity $84.4 \%$ and $93.3 \%$ respectively, could discriminate CKD without hypertension from control. Zhang et al. (2019) reported diagnostic value of urinary TNF- $\alpha$ for early detection of DN from T2D at cutoff 10.46 with sensitivity $65.96 \%$

\section{Conclusion}

Results clarified interestingly the inflammatory determinants of CKD based on down-regulation of TTP and up-regulation of TNF- $\alpha$ in CKD patients versus healthy ones. Hypertension and diabetes modulate expression of these inflammatory biomarkers owing to correlations noticed in CKD. TTP and TNF- $\alpha$ may represent therapeutic targets for renal inflammation which need to be explored in larger samples. 


\section{REFERENCES}

Abd Elhafeez, S., Bolignano, D., D'Arrigo, G., Dounousi, E.Tripepi, G., \& Zoccali, C. (2018). Prevalence and burden of chronic kidney disease among the general population and high-risk groups in Africa: A systematic review. BMJ Open, 8(1).

Al-Lamki, R. S., \& Mayadas, T. N. (2015). TNF receptors:

Signaling pathways and contribution to renal dysfunction. Kidney International, 87(2), 281-296.

Astakhova, A.A., Chistyakov, D.V., Sergeeva, M.G., Reiser, G. (2018). Regulation of the ARE-binding proteins, TTP (tristetraprolin) and HuR (human antigen R), in inflammatory response in astrocytes. Neurochem Int., 118:82-90.

Bollmann, F., Wu, Z., Oelze, M., Siuda, D., Xia, N., Henke, J., Daiber, A., Li, H., Stumpo, D.J., Blackshear, P.J., Kleinert, H., Pautz, A. (2014). Endothelial dysfunction in tristetraprolindeficient mice is not caused by enhanced tumor necrosis factor- $\alpha$ expression. J Biol Chem. 30; 289(22): 15653-65.

Chen, X., Wei, Z., Wang, W., Yan, R., Xu, X., Cai, Q. (2012). Role of RNA-binding protein tristetraprolin in tumor necrosis factor$\alpha$ mediated gene expression. Biochem Biophys Res Commun. 23; 428(3):327-32.

Chopra H.K.and Ram C.V.( 2019). Recent guidelines for hypertension: a clarion call for blood pressure control in India. Circulation research, 124(7), 984-986.

Ernandez, T. and Mayadas, T. (2009). Immunoregulatory role of $\mathrm{TNF} \alpha$ in inflammatory kidney diseases. Kidney International. 76, 262-276.

Faniello, M.C., Di Sanzo, M., Quaresima, B., Baudi, F., Di Caro, V., Cuda, G., Morrone, G., ... Costanzo, F. (2008). p53-Mediated downregulation of $\mathrm{H}$ ferritin promoter transcriptional efficiency via NF-Y. Int. J. Biochem. Cell Biol. 40, 2110-2119. 
Feigerlová, E., Battaglia-Hsu, (2017). Role of post transcriptional regulation Of mRNA Stability in renal pathophysiology : focus on chronic kidney disease. FASEB J.31 (2):457-468.

Hill, N. R., Fatoba, S. T., Oke, J. L., Hirst, J. A., O'Callaghan, C. A., Lasserson, D. S., \& Hobbs, F. D. R. (2016). Global Prevalence of Chronic Kidney Disease - A Systematic Review and Meta-Analysis. PloS One, 11(7).

Livak KJ. and Schmittgen TD.(2001). Analysis of relative gene expression data using real-time quantitative PCR and the 2(-Delta Delta C(T)) Method. Dec;25(4):402-8.

Levey, A.S., Coresh, J., Greene, T. et al (2006). Using standardized serum creatinine values in the modification of diet in renal disease study equation for estimating glomerular filtration rate. Ann Intern Med 145:247-254.

Levey, A.S., Coresh, J.(2012). Chronic kidney disease. Lancet. 14; 379(9811):165-80.

Liu, F., Guo, J., Zhang, Q., Liu, D., Wen, L., Yang, Y., ... Liu, Z. (2015). The expression of tristetraprolin and its relationship with urinary proteins in patients with diabetic nephropathy. PLoS ONE, 10(10).

Mihai, S., Codrici, E., Popescu, I. D., Enciu, A.-M., Albulescu, L., Necula, L. G., Tanase, C. (2018). Inflammation-Related Mechanisms in Chronic Kidney Disease Prediction, Progression, and Outcome. Journal of Immunology Research, 2018, 1-16.

Nourian, M., Chaleshi, V., Pishkar, L., Azimzadeh, P., Baradaran Ghavami, S., Balaii, H., ... Zali, M.R. (2017). Evaluation of tumor necrosis factor (TNF)- $\alpha$ mRNA expression level and the rs1799964 polymorphism of the TNF- $\alpha$ gene in peripheral mononuclear cells of patients with inflammatory bowel diseases. Biomed. reports 6, 698702.

Ortega, L. M., \& Alessia, F. (2010). Role of cytokines in the pathogenesis of acute and chronic kidney disease, glomerulonephritis, and end-stage kidney disease. International Journal of Interferon, 
Cytokine and Mediator Research, 2(1), 49-62.

Puszkarska, A., Niklas, A., Gluszek, J., Lipski, D., Niklas, K. (2019). The concentration of tumor necrosis factor in the blood serum and in the urine and selected early organ damages in patients with primary systemic arterial hypertension. Medicine (Baltimore). 98 (22):e15773.

Rahman, M. M., Rumzhum, N. N., Hansbro, P. M., Morris, J. C., Clark, A. R., Verrills, N. M., \& Ammit, A. J. (2016). Activating protein phosphatase 2A (PP2A) enhances tristetraprolin (TTP) antiinflammatory function in A549 lung epithelial cells. Cellular Signalling, 28(4), 325-334.

Wallach, J. (1996). Metabolic and hereditary disorders. In: Interpretation of Diagnostic Tests. 6th ed. Boston, MA: Little Brown and Company.

Xiao, J., Gao, H., Jin, Y., Zhao, Z., Guo, J., Liu, Z., Zhao, Z. (2014). The abnormal expressions of tristetraprolin and the VEGF family in uraemic rats with peritoneal dialysis. Mol Cell Biochem., 392 (1-2) : 229-38.

Zhang, D., Ye, S., and Pan, T. (2019). The role of serum and urinary biomarkers in the diagnosis of early diabetic nephropathy in patients with type 2 diabetes. PeerJ 7:e 7079.

Zhao, X. K., Che, P., Cheng, M. L., Zhang, Q., Mu, M., Li, H., ... Ding, Q. (2016). Tristetraprolin down-regulation contributes to persistent TNF-alpha expression induced by cigarette smoke extract through a post- transcriptional mechanism. PLoS ONE, 11(12), 1-19. 


\section{الملخص العربي}

تقييم الدور التحفيزي للتعبير الجيني لتريستيتر ابرولين و معامل النخر الورمي الفا في مرض اليز الكلي المزمن الترن

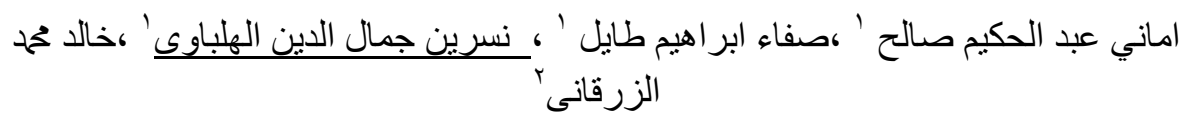
قسمى' الكيمياء الحيوية الطبية و البيولوجيا الجزيئية ، 'الباطنة العامة كلية الطب- جامعة المنوفية

يـرتبط مـرض الكلى المـزمن بحـدوث التهابـات ـ ويعـد تريستيترابرولين و معامـل النخـر



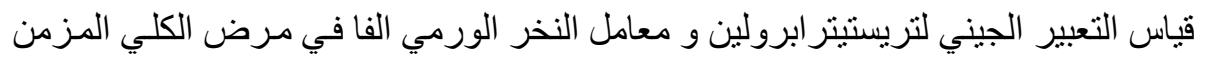

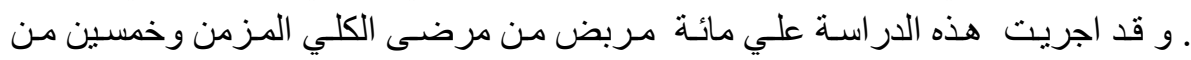



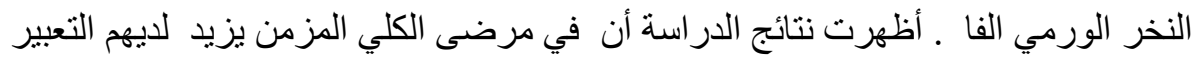

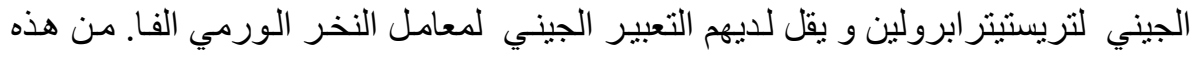

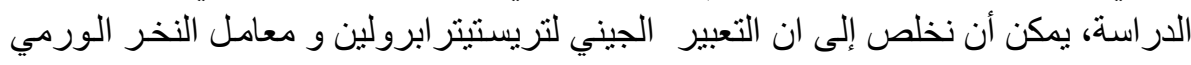

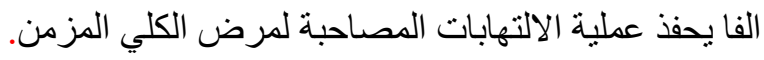

